\title{
Using Generic Pheromone Lures to Expedite Identification of Aggregation Pheromones for the Cerambycid Beetles Xylotrechus nauticus, Phymatodes lecontei, and Neoclytus modestus modestus
}

\author{
Lawrence M. Hanks • Jocelyn G. Millar • \\ Jardel A. Moreira • James D. Barbour • \\ Emerson S. Lacey • J. Steven McElfresh • \\ F. Ray Reuter $\cdot$ Ann M. Ray
}

Received: 9 January 2007 / Accepted: 23 February 2007 /

Published online: 29 March 2007

(C) Springer Science + Business Media, LLC 2007

\begin{abstract}
Males of several species of longhorned beetles in the subfamily Cerambycinae produce sex or aggregation pheromones consisting of 2,3-hexanediols and/or hydroxyhexanones. We tested the hypothesis that this diol/hydroxyketone pheromone motif is highly conserved within the subfamily, and the resulting prediction that multiple cerambycine species will be attracted to compounds of this type. We also tested the concept that live traps baited with generic blends of these compounds could be used as a source of live insects from which pheromones could be collected and identified. Traps placed in a mature oak woodland and baited with generic blends of racemic 2-hydroxyhexan-3-one and 3hydroxyhexan-2-one captured adults of both sexes of three cerambycine species: Xylotrechus nauticus (Mannerheim), Phymatodes lecontei Linsley, and Phymatodes decussatus decussatus (LeConte). Odors collected from male X. nauticus contained a 9:1 ratio of two male-specific compounds, $(R)$ - and $(S)$-3-hydroxyhexan-2-one. Field trials with synthetic compounds determined that traps baited with $(R)$-3-hydroxyhexan-2-one (94\% ee), alone or in blends with other isomers, attracted similar numbers of $X$. nauticus of both sexes, whereas $(S)$-3-hydroxyhexan-2-one (94\% ee) attracted significantly fewer beetles. Phymatodes lecontei and $P$. $d$. decussatus also were caught in traps baited with hydroxyhexanones, as well as a few specimens of two other cerambycine species, Neoclytus modestus modestus Fall (both sexes) and Brothylus gemmulatus LeConte (only females). Male N. m. modestus produced (R)-3-hydroxyhexan-2-one, which was not present
\end{abstract}

L. M. Hanks $(\bowtie) \cdot$ E. S. Lacey $\cdot$ A. M. Ray

Department of Entomology, University of Illinois at Urbana-Champaign, Urbana, Illinois 61801, USA

e-mail: hanks@uiuc.edu

J. G. Millar J J. A. Moreira • J. S. McElfresh • F. R. Reuter

Department of Entomology, University of California, Riverside, California 92521, USA

J. D. Barbour

Parma Research and Extension Center, University of Idaho, Parma, Idaho 83660-6590, USA 
in extracts from females. Neoclytus m. modestus of both sexes also responded to lures that included $(R)$-3-hydroxyhexan-2-one as one of the components. The only male-specific compound found in extracts from $P$. lecontei was (R)-2-methylbutan-1-ol, and adults of both sexes were attracted to racemic 2-methylbutan-1-ol in field bioassays. Surprisingly, $P$. lecontei of both sexes also were attracted to $(R)$ - and $(S)$-3-hydroxyhexan-2-ones, although neither compound was detected in extracts from this species. Males of all five beetle species had gland pores on their prothoraces that were similar in structure to those that have been associated with volatile pheromone production in other cerambycine species. The attraction of multiple cerambycine species of two tribes to $(R)$-3-hydroxyhexan-2-one in this study, and in earlier studies with other cerambycine species, suggests that this compound is a widespread aggregation pheromone component in this large and diverse subfamily. Overall, the attraction of multiple species from different cerambycine tribes to this compound at a single field site supports the hypothesis that the hydroxyketone pheromone structural motif is highly conserved within this subfamily.

Keywords Aggregation pheromone $\cdot$ Cerambycidae $\cdot(R)$-3-Hydroxyhexan-2-one $\cdot$ Insect communities $\cdot$ Sex pheromone $\cdot$ Woodborer

\section{Introduction}

Males of several longhorned beetle species in the subfamily Cerambycinae produce volatile sex or aggregation pheromones (Lacey et al. 2007a). These pheromones are comprised of one to three compounds that share a similar structural motif consisting of molecules that are six, eight, or 10 carbons in length, with hydroxyl or carbonyl groups at $\mathrm{C}_{2}$ and $\mathrm{C}_{3}$ (reviewed by Lacey et al. 2004, 2007a). The pheromones are produced by sex-specific glands in the prothorax of males that discharge through pores situated within depressions in the cuticle (Ray et al. 2006; Lacey et al. 2007b). A morphological survey of 65 cerambycine species revealed that 49 species in 14 tribes had analogous male-specific prothoracic pores, suggesting that volatile pheromones may play an important role in reproduction or other behaviors for many species in this subfamily (Ray et al. 2006). The Cerambycinae is represented by at least 1,100 species in North America alone (excluding Mexico; Yanega 1996). Given this taxonomic diversity, and the many cerambycine species that have male-specific gland pores, it is likely that multiple species that produce volatile pheromones will be present in any given geographic area.

In this paper, we report the results of studies that tested the hypothesis that the diol/ hydroxyketone pheromone motif is highly conserved within the Cerambycinae, and the resulting prediction that multiple cerambycine species will be attracted to compounds of this type. We chose six-carbon compounds for this first test of the hypothesis, rather than eight- or ten-carbon homologs, because all 10 North American cerambycine species that we have worked with previously were found to produce $\mathrm{C}_{6}$ pheromones (Lacey et al. 2004, 2007a; Ray et al. 2006; unpublished data). Thus, 2,3-hexanediols, 2-hydroxyhexan-3-ones, and 3-hydroxyhexan-2-ones were synthesized and deployed as trap lures in field bioassays. Beetles that were attracted to the test compounds were trapped live, and the volatiles that they released were collected and analyzed to identify the actual pheromone compounds produced by each species. We report here the species that responded to the synthetic hexanediol and hydroxyhexanone lures in field bioassays conducted in one area of southern California. We further report the identification of pheromone components for three of these cerambycine species, Xylotrechus nauticus (Mannerheim), Phymatodes lecontei Linsley, 
and Neoclytus modestus modestus Fall. We also characterize the morphology of the likely gland pores for each cerambycine species that was captured.

\section{Methods and Materials}

Synthetic Pheromones

A mixture of 2,3-hexanediols (henceforth generic hexanediols) was synthesized as follows (Scheme 1a). A solution of 2,3-hexanedione (114.15 g, $1.0 \mathrm{~mol}$; Aldrich Chemical Co., Milwaukee, WI, USA; $>90 \%$ purity) in ethanol (EtOH, $200 \mathrm{ml}$ ) was added over $3 \mathrm{hr}$ to a stirred mixture of $\mathrm{NaBH}_{4}(26.5 \mathrm{~g}, 0.70 \mathrm{~mol})$ in $\mathrm{EtOH}(300 \mathrm{ml})$ at $0^{\circ} \mathrm{C}$ under argon. The reaction was warmed to room temperature and stirred overnight. The resulting mixture was concentrated, then poured into a stirred mixture of brine $(500 \mathrm{ml})$ and $6 \mathrm{M} \mathrm{HCl}(200 \mathrm{ml})$, and extracted with ethyl acetate $(5 \times 200 \mathrm{ml})$. The combined organic phases were washed with saturated aqueous $\mathrm{NaHCO}_{3}$, dried over anhydrous $\mathrm{Na}_{2} \mathrm{SO}_{4}$, and concentrated by rotary evaporation. The residue was purified by Kugelrohr distillation (oven temperature $81-90^{\circ} \mathrm{C}, 3.0 \mathrm{~mm} \mathrm{Hg}$ ) affording $90.42 \mathrm{~g}(77 \%$ yield $)$ of a mixture of racemic $\left(2 R^{*}, 3 R^{*}\right)$-hexanediol and $\left(2 R^{*}, 3 S^{*}\right)$-hexanediol (36:64, respectively: GC analysis on DB-5 column, $30 \mathrm{~m} \times 0.32 \mathrm{~mm}$ i.d., $0.25 \mu \mathrm{m}$ film; J\&W Scientific, Folsom, CA, USA; temperature program $40^{\circ} \mathrm{C} / 1 \mathrm{~min}, 10^{\circ} / \mathrm{min}$ to $250^{\circ}$, helium carrier gas, head pressure $105 \mathrm{kPa}$, injector and detector temperatures, $250^{\circ} \mathrm{C}$ ). The mass spectra and retention times matched those of standards (Lacey et al. 2004; GC-MS analysis, HP 5973 mass selective detector coupled to an HP 6890 GC [Hewlett-Packard, Avondale, PA, USA] fitted with an HP5-MS column, $30 \mathrm{~m} \times 0.25 \mathrm{~mm}$ i.d., $0.25 \mu \mathrm{m}$ film, temperature program $40^{\circ} \mathrm{C} / 1 \mathrm{~min}, 10^{\circ} / \mathrm{min}$ to $250^{\circ}$, helium carrier gas, $36 \mathrm{~cm} / \mathrm{sec}$ linear flow, injector and transfer line temperatures, $250^{\circ} \mathrm{C}$ ).

A blend of 2,3-hydroxyhexanones for bioassay trap lures (henceforth generic hydroxyhexanones), consisting of a mixture of racemic 2-hydroxyhexan-3-one and 3hydroxyhexan-2-one, was synthesized as shown in Scheme 1b. A suspension of $\mathrm{NaBH}_{4}$ (3.73 g, $99 \mathrm{mmol})$ in $\mathrm{EtOH}(80 \mathrm{ml})$ was added dropwise over $2 \mathrm{hr}$ to a stirred solution of 2,3-hexanedione (30.00 g, $263 \mathrm{mmol}$; Aldrich Chem. Co.) in EtOH $(60 \mathrm{ml})$ at $0^{\circ} \mathrm{C}$. The resulting mixture was stirred for $8 \mathrm{hr}$ at $0^{\circ} \mathrm{C}$, and then allowed to warm to room temperature and stirred overnight. Water $(150 \mathrm{ml})$ was added and the reaction was extracted with pentane:diethyl ether $\left(\mathrm{Et}_{2} \mathrm{O}\right)(1: 1-5 \times 100 \mathrm{ml})$. The combined organic extracts were washed

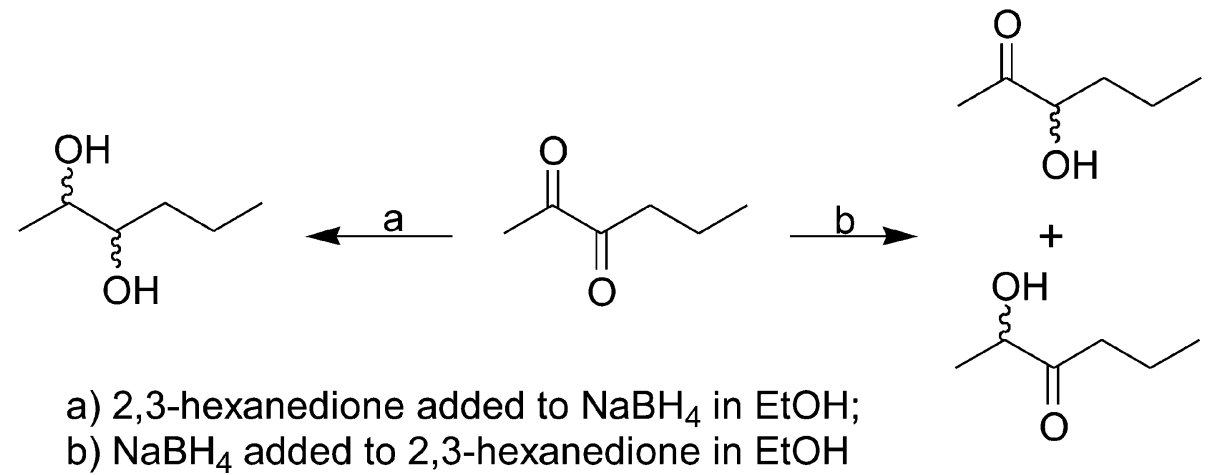

Scheme 1 Synthesis of generic blends of 2,3-hexanediols and 2,3-hydroxyhexanones 
with brine, dried over $\mathrm{Na}_{2} \mathrm{SO}_{4}$, and the solvent was removed by fractional distillation through a Vigreux column (fractional distillation was essential because concentration by rotary evaporation resulted in loss of the product). The residue was purified by vacuum flash chromatography (pentane/ $\mathrm{Et}_{2} \mathrm{O}$ 95:5 until all unreacted 2,3-hexanedione had been removed, then pentane/ $/ \mathrm{Et}_{2} \mathrm{O} 4: 1$ ). The solvent was removed by distillation through a Vigreux column, and the product was Kugelrohr distilled (oven temperature $40-45^{\circ} \mathrm{C}, 2.1 \mathrm{~mm} \mathrm{Hg}$ ) affording $13.81 \mathrm{~g}$ (45.2\% yield) of a mixture of racemic 2-hydroxyhexan-3-one and 3hydroxyhexan-2-one (59:41, respectively). Retention times and mass spectra of the two isomers matched those of authentic standards (Lacey et al. 2007a). The positional isomers were not separated on a DB-5 GC column, but both the positional isomers and the enantiomers were resolved on a chiral phase Cyclodex B column $(30 \mathrm{~m} \times 0.25 \mathrm{~mm}$ i.d. $\times$ $0.25 \mu \mathrm{m}$ film, J\&W Scientific; temperature program $50^{\circ} \mathrm{C} / 1 \mathrm{~min}, 5^{\circ} / \mathrm{min}$ to $250^{\circ}$, helium carrier gas, head pressure $150 \mathrm{kPa}$, injector temperature $100^{\circ} \mathrm{C}$ and detector temperatures $\left.250^{\circ} \mathrm{C}\right)$. The four hydroxyhexanones eluted in the order $(2 R)(10.49 \mathrm{~min}),(3 R)(10.56 \mathrm{~min})$, $(2 S)(10.67 \mathrm{~min})$, and $(3 S)(11.10 \mathrm{~min})$. It was crucial to use an injector temperature of $100^{\circ}$ $\mathrm{C}$ to prevent thermal isomerization of the hydroxyhexanones (Leal et al. 1995).

Racemic 3-hydroxyhexan-2-one and enantiomerically enriched $(R)$-3-hydroxyhexan-2one and ( $S$ )-3-hydroxyhexan-2-one (both $94 \%$ ee) were synthesized as previously described (Lacey et al. 2007a). Racemic 2-methylbutan-1-ol (98\%) was obtained from Alfa Aesar (Heysham, Lancashire, UK) and (S)-2-methylbutan-1-ol (99\%) was obtained from Aldrich Chemical Co. The enantiomers of 2-methyl-1-butanol were resolved on the Cyclodex B column with a temperature program of $40^{\circ} \mathrm{C} / 10 \mathrm{~min}, 5^{\circ} / \mathrm{min}$ to $200^{\circ} \mathrm{C}$, with other operating conditions as described above. Under these conditions, the $(R)$-enantiomer eluted at $13.64 \mathrm{~min}$, whereas the $(S)$-enantiomer eluted at $13.82 \mathrm{~min}$.

Screening Bioassays to Target Species for Pheromone Identification

We targeted species for pheromone identification by baiting traps for collecting live insects with generic hexanediols, generic hydroxyhexanones, or a 1:1 blend of the two. The mixtures were diluted with absolute EtOH (Gold Shield Co., Hayward, CA, USA) (100 mg/ $\mathrm{ml}$ for the single compounds, $100 \mathrm{mg} / \mathrm{ml}$ each for the blend), and loaded into lures $(1 \mathrm{ml} /$ lure) consisting of 0.5 dram glass vials with open-top screw caps closed with PTFE-faced silicone septa (Cat. no. 03-393F, Fisher Scientific, Fairlawn, NJ, USA). The septum was pierced with a $2-\mathrm{cm}$ piece of glass tubing ( $2 \mathrm{~mm}$ i.d.), and a pipe cleaner wick (cotton and steel wire; $40 \mathrm{~mm}$ long) was inserted through the tubing. The basal $0.5 \mathrm{~cm}$ of the wick was bent at a $90^{\circ}$ angle and was in contact with the bottom of the vial, and the other end protruded $\sim 1 \mathrm{~mm}$ beyond the top of the glass tube. A preliminary experiment demonstrated that ethanol was an efficient carrier for the hexanediols and hydroxyhexanones, and that lures would release $1 \mathrm{ml}$ of ethanol solution over the course of 2 d outdoors (conducted 2325 May 2006, in shade, daily minimum air temperatures $13-15^{\circ} \mathrm{C}$, maximum temperatures $26-31^{\circ} \mathrm{C}$ ). Lures were hung with wire in cross-vane flight-intercept panel traps (black, $80 \times$ $30 \mathrm{~cm}$, Intercept ${ }^{\mathrm{TM}}$, model PT, Advanced Pheromone Technologies, Marylhurst, OR, USA). To capture beetles alive, traps were modified by replacing the supplied collection basin with a 1.9-1 plastic funnel with the spout shortened to give a 35-mm-diameter hole. The threaded lid ring from a wide mouth $960 \mathrm{ml}$ canning jar (Alltrista Consumer Products Co., Muncie, IN, USA) was placed over the spout and glued to the bowl of the funnel so that the jar could be attached with the spout inside the jar. The upper halves of jar interiors, interior surfaces of funnels, and surfaces of trap panels were treated with Rain- ${ }^{\circledR}$ (Houston, TX, USA) glass treatment to render them slippery (Sweeney et al. 2006). Trap hangers were 
constructed of $1.27 \mathrm{~cm}$ i.d. PVC pipe (D1785, Schedule 40, Charlotte Pipe and Foundry Co., Charlotte, NC, USA), with a 1.5 -m-long upright connected with a T-fitting to a $20-\mathrm{cm}$ long arm having a loop of wire at the end to which the trap was attached. The upright was mounted on a $1.5-\mathrm{m}$ section of $1.27-\mathrm{cm}$-diam steel reinforcing bar that was driven part way into the ground.

The three treatments (generic hexanediols, generic hydroxyhexanones, 1:1 blend of generic hexanediols and hydroxyhexanones) were randomly assigned to traps. Because the purpose of the experiment was to trap live beetles for pheromone collection, and not to identify specific attractants, controls were not used. A single set of traps was set up at the Santa Rosa Plateau Reserve (Riverside Co., CA, USA) in late afternoons of $4 \mathrm{~d}$ between 24 May and 2 June 2006, skies clear, maximum air temperatures $25-31^{\circ} \mathrm{C}$. Traps were positioned $15 \mathrm{~m}$ apart in a southwesterly transect through a grassland area wooded with mature Quercus agrifolia Née (position of trap \# 1: $33^{\circ} 31^{\prime} 58.12^{\prime \prime} \mathrm{N}, 117^{\circ} 15^{\prime} 49.94^{\prime \prime} \mathrm{W}$ ). There were many dead trees and downed limbs of various ages at the site. Traps were checked daily for beetles, and captured beetles were taken to the laboratory and separated by species and sex into cylindrical aluminum screen cages (6-cm diam, $10 \mathrm{~cm}$ tall, with plastic Petri dishes at top and bottom). Beetles were provided a cotton roll saturated with $10 \%$ sucrose solution for water and nutrition. Treatments were rotated one position on each collection date.

\section{Identification of Pheromone Components}

Adult beetles of each sex were placed individually into two-piece glass vacuum traps ( $\sim .3$ 1, ground glass fittings; UIUC School of Chemical Sciences glass shop) lined with aluminum screen as perches. A section of glass tubing containing $100 \mathrm{mg}$ of 80/100 mesh SuperQ ${ }^{\circledR}$ (Alltech Associates, Deerfield, IL, USA) was attached to the outlet of each vacuum trap with a 2-cm long section of Teflon ${ }^{\circledR}$ tubing, and charcoal-purified air (6-14 mesh, Fisher Scientific, Pittsburgh, PA, USA) was pulled through the apparatus by vacuum at a rate of $11 / \mathrm{min}$. The chambers were placed on the laboratory windowsill and volatiles were collected from adult beetles from 18:00 to 0:00 hr. The SuperQ ${ }^{\circledR}$ collectors then were eluted with $0.5 \mathrm{ml}$ dichloromethane $\left(\mathrm{CH}_{2} \mathrm{Cl}_{2}\right)$, and extracts were analyzed by gas chromatography-mass spectroscopy (GC-MS) on the HP5-MS column by using identical conditions as described earlier, except that injections were made in splitless mode and the injector temperature was $100^{\circ} \mathrm{C}$. The absolute configurations of the insect-produced chiral compounds (see "Results") were determined by analysis of extracts on the Cyclodex B column, as described above and confirmed by co-injection of an aliquot of the insect extract spiked with the appropriate standards.

To quantify the amount of pheromone produced by $X$. nauticus, male beetles collected in field bioassays were placed individually in small aeration chambers constructed from 237$\mathrm{ml} \mathrm{Ball}{ }^{\circledR}$ canning jars (Alltrista Consumer Products Co.) with two holes punched in the lid to accommodate $0.64 \mathrm{~cm} \mathrm{Swagelok}^{\circledR}$ unions for attaching inlet and outlet lines. The inlet was fitted with a $15 \times 1.5 \mathrm{~cm}$ copper tube filled with activated charcoal granules (6-14 mesh, Fisher Scientific, Pittsburgh, PA, USA), and the outlet was fitted with a trap consisting of a $4.5 \mathrm{~cm} \times 3 \mathrm{~mm}$ i.d. glass tube with a 5 -mm plug of activated charcoal (50-200 mesh, Fisher Scientific, Pittsburgh, PA, USA) held in place by two glass wool plugs. Each chamber was equipped with a 1/2-dram vial filled with water, with the neck of the vial plugged with a cotton swab. Air was pulled through each chamber by vacuum at $\sim 500 \mathrm{ml} / \mathrm{min}$. Aerations were continued for $1-6 \mathrm{~d}$ (some beetles died during aerations), in a brightly lit environmental chamber at $25^{\circ} \mathrm{C}$ and $\sim 50 \% \mathrm{RH}, 14 \mathrm{~L}: 10 \mathrm{D}$. Traps were eluted with $0.4 \mathrm{ml}$ of $\mathrm{CH}_{2} \mathrm{Cl}_{2}$ into tared vials, and the vials were then reweighed to calculate the total weight. 
Total volume of each extract was then determined by dividing the mass by the density of the solvent. One-microliter aliquots of each extract were analyzed by GC (as described above), and the total amount of pheromone in each extract was calculated by comparison with an external standard curve $\left(5-500 \mu \mathrm{g} / \mathrm{ml}\right.$, regression $\left.r^{2}=0.996\right)$. Of 13 extracts collected, eight contained detectable amounts of pheromone.

Field Bioassays of Synthetic Compounds, Targeting Particular Species

We conducted field bioassays of synthetic compounds on 5 d between 13 and 19 June 2006, skies clear, maximum air temperatures $24-36^{\circ} \mathrm{C}$. Compounds were formulated in EtOH, and lures were loaded with $1 \mathrm{ml}$ of the resulting solutions. There were eight treatments that were randomly assigned to traps, as follows:

1) blank control (empty vial);

2) EtOH control;

3) racemic 2-methylbutan-1-ol (50 mg in $1 \mathrm{ml} \mathrm{EtOH})$; although male $P$. lecontei produced $(R)$-2-methylbutan-1-ol (see "Results"), we used racemic 2-methylbutan-1-ol in lures because the $(R)$-enantiomer was not commercially available, and there was insufficient time left in the field season to synthesize the $(R)$-enantiomer for testing;

4) (R)-3-hydroxyhexan-2-one $(25 \mathrm{mg} / \mathrm{ml})$;

5) (S)-3-hydroxyhexan-2-one $(25 \mathrm{mg} / \mathrm{ml})$;

6) 9:1 blend of $(R)$ - and $(S)$-3-hydroxyhexan-2-one $(25 \mathrm{mg} / \mathrm{ml}$; based on approximate ratios produced by male $X$. nauticus; see "Results");

7) 9:1 blend of $(R)$ - and $(S)$-3-hydroxyhexan-2-one plus 2,3-hexanedione (22.5:2.5:6.6 mg, respectively, in $1 \mathrm{ml} \mathrm{EtOH})$; 2,3-hexanedione was considered an artifact during pheromone identification of another cerambycine species (Fettköther et al. 1995), but was a possible minor component produced by male $X$. nauticus (see "Results");

8) generic blend of hydroxyhexanone stereoisomers $(100 \mathrm{mg} / \mathrm{ml}$; to determine whether responses of adult beetles would be influenced by the presence of the "unnatural" isomers).

We used three sets of eight traps ( 1 trap per treatment), with traps spaced $15 \mathrm{~m}$ apart in linear transects. One set of traps was in the same location as had been used for the screening bioassays (trap \#1 in same position), and the second and third sets were set up among oak trees $0.42 \mathrm{~km}$ to the north and $0.54 \mathrm{~km}$ to the southwest, respectively, of trap \# 1 of the first set. Thus, there was one replicate of each treatment in each of three sets of traps on each of $5 \mathrm{~d}(N=15$ replicates per treatment). Treatments were rotated one position down the trap line on each collection date. Traps, funnels, and jars were cleaned with Windex ${ }^{\circledR}$ glass and surface wipes (S. C. Johnson \& Sons, Inc., Racine, WI, USA), then treated with Rain- $X^{\circledR}$. Captured beetles were collected after $24 \mathrm{hr}$ and the number and sex responding to each treatment were recorded. Lures were replaced as needed (when vials were empty, often after $24 \mathrm{hr}$ ).

Differences between treatments in numbers of beetles captured per trap were tested separately for the two most abundant species, $X$. nauticus and $P$. lecontei, by ANOVA (PROC GLM, SAS Institute 2001), blocked by sample day. Thus, the ANOVA model for each species was: number of beetles captured $=$ treatment $\times$ day. We tested differences between preplanned pairs of treatment means by using orthogonal contrasts (Sokal and Rohlf 1995). Thus, we compared the EtOH control with the blank control (to determine whether EtOH itself was attractive), compared each treatment that contained synthetic compounds with the controls (blank and EtOH controls pooled because they did not differ significantly; see below), and also compared treatments containing $(R)$-3-hydroxyhexan-2-one with each other, 
to determine effects of possible minor components or stereoisomers. We also compared the 2,3-hexanedione plus the 9:1 blend of $(R)$ - and $(S)$-3-hydroxyhexan-2-one to the 9:1 blend alone. Structural failure of a few traps was responsible for slight inconsistencies in degrees of freedom for some analyses. Differences between treatments in the sex ratio of responding $X$. nauticus and P. lecontei were tested with $\chi^{2}$ goodness-of-fit tests.

\section{Location of Pheromone Glands}

To confirm that sex-specific pores were present in the prothoraces of males of the species that were captured during the study (see "Introduction"), we imaged the prothorax of one adult of each sex by scanning electron microscopy (SEM). Specimens were prepared for SEM as described by Ray et al. (2006), and imaged with a Phillips XL30 environmental scanning electron microscope equipped with a field-emission electron gun (FEI Company, Hillsboro, OR, USA) operated at $5.0 \mathrm{kV}$.

To further confirm that pores in the prothorax of male $X$. nauticus and $P$. lecontei were associated with pheromone glands, we sectioned prothoraces of both sexes of each species for light microscopy. One male and one female were chilled, and the entire prothorax was excised. The prothorax samples were fixed in $2.5 \%$ glutaraldehyde and $2.0 \%$ paraformaldehyde in $0.1 \mathrm{M}$ sodium cacodylate buffer, $\mathrm{pH} 7.4$, and held at $<10^{\circ} \mathrm{C}$, then later shipped on ice to the University of Illinois where they were stored at $<10^{\circ} \mathrm{C}$. After a 10 -min buffer rinse, the samples were postfixed in $1 \%$ osmium tetroxide in the same buffer for $90 \mathrm{~min}$ in the dark. After a second buffer rinse, the samples were dehydrated through an extended ascending ethanol series ( $3 \mathrm{hr}$ each in 37,67 , and 95\% ethanol), culminating at $10 \mathrm{hr}$ in $100 \%$ EtOH. The samples were then infiltrated and embedded in Poly/Bed ${ }^{\circledR} 812$ embedding resin plus 2\% (wt/wt) DMP-30 per manufacturer instructions (Polysciences 2003), with the exception that infiltration times were extended to $3 \mathrm{hr}$ for each change, and a 6-hr immersion in fresh resin without DMP-30 was added before the final step. Prothoraces in embedding resin plus DMP-30 were then positioned horizontally in soft plastic molds (\#105; Ted Pella, Inc., Redding, CA, USA) and placed in a $60^{\circ} \mathrm{C}$ oven for $24 \mathrm{hr}$. One-micron-thick sections were cut using an Ultracut UCT ultramicrotome (Leica Microsystems GmbH, Wetzlar, Germany) equipped with a 6-mm histology grade diamond knife (MicroStar Technologies, Huntsville, TX, USA), affixed to standard glass microscope slides (Fisher Scientific, Fairlawn, NJ), and stained with a 1\% toluidine blue solution. Sections were examined using a Nikon Eclipse E600 microscope (Nikon USA, Melville, NY, USA) operated in bright field mode, equipped with a SPOT Insight ${ }^{\mathrm{TM}}$ color camera (Diagnostic Instruments, Sterling Heights, MI, USA).

Voucher specimens of all cerambycid species caught have been submitted to the Entomology Research Museum, University of California, Riverside.

\section{Results}

Screening Bioassays to Target Species for Pheromone Identification

Traps baited with generic lures captured three cerambycine species during the four trials (Table 1): X. nauticus $(N=18)$, P. lecontei $(N=30)$, and Phymatodes decussatus decussatus (LeConte) $(N=6)$. Traps baited with the generic hydroxyhexanone lures and the blend of hydroxyhexanones and hexanediols contained the majority of the beetles caught in these bioassays, with only three beetles of one species ( $P$. lecontei) caught in traps baited with the 
Table 1 Cerambycine adults attracted to generic blends of possible pheromone components (screening experiment, $N=4$ days) or enantiomerically enriched pheromone components (targeted experiment, $N=$ 5 days $)^{\mathrm{a}}$

\begin{tabular}{|c|c|c|c|c|c|c|c|c|c|c|}
\hline \multirow[t]{2}{*}{ Expt. } & \multirow[t]{2}{*}{ Treatment } & \multicolumn{2}{|c|}{$\begin{array}{l}\text { Xylotrechus } \\
\text { nauticus }\end{array}$} & \multicolumn{2}{|c|}{$\begin{array}{l}\text { Phymatodes } \\
\text { lecontei }\end{array}$} & \multicolumn{2}{|c|}{$\begin{array}{l}\text { Phymatodes } \\
\text { decussatus }\end{array}$} & \multicolumn{2}{|c|}{$\begin{array}{l}\text { Neoclytus } \\
m . \\
\text { modestus }\end{array}$} & $\begin{array}{l}\text { Brothylus } \\
\text { gemmulatus }\end{array}$ \\
\hline & & 우 & $\widehat{\delta}$ & q & $\widehat{\delta}$ & q & 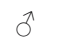 & q & $\hat{\sigma}$ & $\hat{\delta}$ \\
\hline Screening & Generic hydroxyhexanones & 5 & 3 & 5 & 12 & 3 & 3 & & & \\
\hline Screening & Generic hexanediols & & & & 3 & & & & & \\
\hline Screening & $\begin{array}{l}\text { Generic hydroxyhexanones }+ \\
\text { generic hexanediols }\end{array}$ & 5 & 5 & 5 & 5 & & & & & \\
\hline Targeted & Blank control & 1 & 1 & & 1 & & & & & \\
\hline Targeted & Ethanol control & 1 & 4 & 2 & 5 & & & & & \\
\hline Targeted & 2-Methylbutan-1-ol & 1 & 3 & 19 & 12 & 3 & & & & \\
\hline Targeted & $(R)$-3-Hydroxyhexan-2-one & 16 & 28 & 27 & 38 & & 1 & 2 & 1 & 1 \\
\hline Targeted & $(S)$-3-Hydroxyhexan-2-one & 9 & 6 & 24 & $12 *$ & & 1 & & & \\
\hline Targeted & $\begin{array}{l}\text { 9:1 Blend of }(R) \text { - and }(S)-3 \text { - } \\
\text { hydroxyhexan-2-one }\end{array}$ & 27 & 18 & 19 & $37 *$ & & & 2 & & 3 \\
\hline Targeted & $\begin{array}{l}\text { 9:1 Blend of }(R) \text { - and }(S)-,+ \\
\text { 2,3-hexanedione }\end{array}$ & 24 & 21 & 13 & 19 & & & 4 & 3 & \\
\hline Targeted & Generic hydroxyhexanones & 30 & 23 & 16 & 28 & & & 2 & 1 & 2 \\
\hline
\end{tabular}

${ }^{\mathrm{a}}$ Asterisks indicate statistically significant departures from 1:1 sex ratios $\left(\chi^{2}, P<0.05\right)$.

generic hexanediols alone (Table 1). A few specimens of other types of insects were caught in traps in this and the subsequent targeted studies, including earwigs, cockroaches, and bark beetles. These nontarget species were captured in all treatments, including blank controls. There was no indication that they were responding to the hydroxyhexanones or hexanediols, with the possible exception of a trogositid beetle, Temnochila chlorodia (Mannerheim), a few of which were captured in the targeted study (see below).

\section{Identification of Pheromone Components}

GC-MS analyses of extracts of volatiles collected from male $X$. nauticus typically showed a single major peak in the total ion chromatogram, which was absent in analogous headspace extracts of females (Fig. 1a). The retention time and mass spectrum of the compound (base peak at $\mathrm{m} / \mathrm{z} 55$, other significant fragments at $\mathrm{m} / \mathrm{z} 43$ [78\%], 73 [53\%], and 45 [26\%]) matched those of a synthetic standard of 3-hydroxyhexan-2-one. The enantiomeric composition of the insect-produced compound was determined to be $\sim 90 \%(R)$ and $10 \%$ $(S)$ by analysis on the Cyclodex-B column, with baseline resolution of the enantiomers. In one extract with a particularly large amount of male-produced compounds (Fig. 1a), we also detected 2,3-hexanedione ( $25 \%$ of the major peak), the identity of which was confirmed by comparison of its retention time and mass spectrum with those of an authentic standard. Under laboratory conditions, males produced $92 \pm 104 \mu \mathrm{g}$ (mean \pm S.D., range 2-310 $\mu \mathrm{g}$ / day, $N=8$ ), of 3-hydroxyhexan-2-one per day.

Collection and analysis of headspace volatiles from both sexes of $N$. m. modestus caught in targeted field trials (see below) revealed that males produced pure $(R)$-3-hydroxyhexan2-one as the only detectable component (identified as described above for $X$. nauticus). This compound was not found in aeration extracts of females. 
Extracts of headspace volatiles from male P. lecontei contained a single peak that was absent in analogous extracts from females (Fig. 1b). The compound was tentatively identified as 2-methylbutan-1-ol by matching its mass spectrum with a database spectrum (NIH-NBS mass spectral database), and the identification was confirmed by comparisons with the spectrum and retention times of an authentic standard. The absolute configuration of the insect-produced compound was determined to be $(R)$ by analysis on the Cyclodex-B column. There was no evidence of hydroxyhexanones or hexanediols in extracts of headspace volatiles collected from $P$. lecontei.

\section{Field Bioassays of Synthetic Compounds Targeting Particular Species}

Five species of cerambycines were caught in the targeted field bioassays (Table 1), including the same three species captured previously in the screening bioassay, $X$. nauticus (109 females, 104 males), P. lecontei (120 females, 152 males), and P. decussatus (three females, two males). In addition, a few Neoclytus modestus modestus (10 females, five males), and Brothylus gemmulatus LeConte (six females) also were caught during these

Fig. 1 Total ion chromatograms (a) of extracts of headspace volatiles produced by adult male (upper trace) and female (lower, inverted trace) Xylotrechus nauticus. The early eluting peak is 2,3hexanedione, and the later eluting peak is a 9:1 mixture of $(R)$ - and $(S)$-3-hydroxyhexan-2-one. Total ion chromatograms (b) of extracts of headspace volatiles produced by adult male (upper trace) and female (lower, inverted trace) Phymatodes lecontei (bottom). The large peak of $(R)$-2-methylbutan-1-ol in the extract from males is split because of incomplete cold trapping on the GC column during the splitless injection. An HP-5MS column was used for all analyses (see "Methods and Materials" for details)
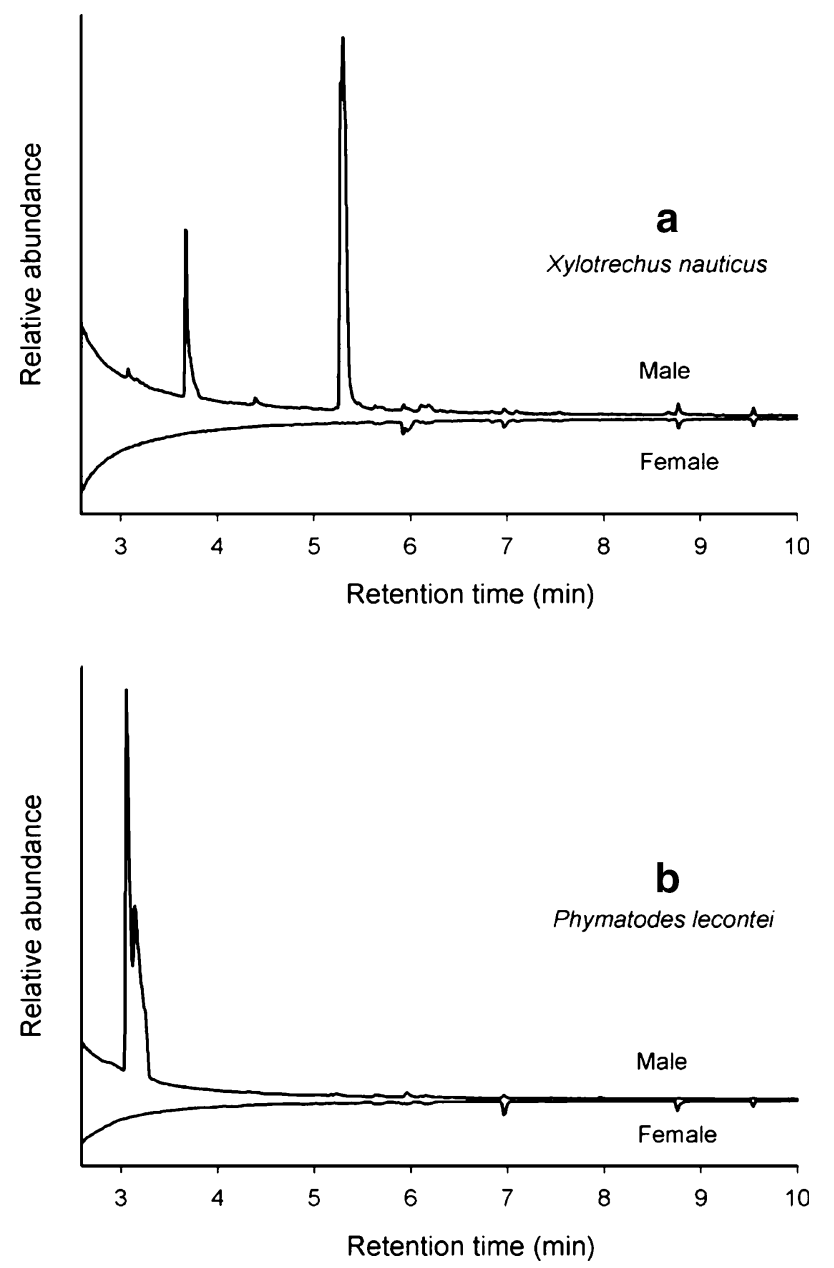
trials. The maximum numbers of beetles caught per trap in a 24-hr period were $19 X$. nauticus in a trap baited with generic hydroxyhexanone and 14 P. lecontei in a trap baited with the 9:1 blend of $(R)$ - and (S)-3-hydroxyhexan-2-one.

Treatments differed significantly in the number of adult $X$. nauticus and $P$. lecontei that were captured (Fig. 2; sexes combined, overall ANOVA for $X$. nauticus $F_{11,105}=3.67, P<$ 0.001 , for $P$. lecontei, $\left.F_{11,105}=4.90, P<0.001\right)$. The day effect was significant for $X$. nauticus $(P=0.005)$ and $P$. lecontei $(P=0.002)$. Numbers of both species captured with ethanol controls were not different from those captured with blank controls (orthogonal contrast, $P>0.65$ ). There was considerable variation in the numbers of beetles captured over time, with mean capture rates for the most attractive treatments (those that contained $(R)-3$ hydroxyhexan-2-one alone or in blends) ranging from $3.5 \pm 0.8$ (S.E.) to $11.9 \pm 2.0$ beetles of all cerambycid species per trap per day. There was no evidence that capture rates for any particular treatment were related to either air temperature or sample date (data not presented).

Mean trap catches of $X$. nauticus for all treatments that contained ( $R$ )-3-hydroxyhexan-2one were significantly different from the combined controls (Fig. 2a), and were not significantly different from one another (contrast $P>0.5$ ). The response to $(S)$-3hydroxyhexan-2-one was not different from the response to the controls (Fig. 2a). Sex ratios of trapped $X$. nauticus were not significantly different from 1:1 for all treatments $\left(\chi^{2}\right.$, $P>0.05)$. Addition of 2,3-hexanedione to a 9:1 blend of $(R)$ - and $(S)$-3-hydroxyhexan-2-one had no effect on trap captures (contrast $P>0.9$ ). The 2-methylbutan-1-ol treatment was not attractive to $X$. nauticus (Fig. 2a; orthogonal contrast versus controls, $P>0.7$ ).

Fig. 2 Relationship between the mean number of adult Xylotrechus nauticus (a) and Phymatodes lecontei (b) captured per trap per day (sexes combined) and stereoisomeric composition of the lure. Treatments were: 1) blank control; 2) EtOH control; 3) racemic 2-methylbutan-1-ol; 4) (R)-3-hydroxyhexan-2-one (94\% ee); 5) (S)-3-hydroxyhexan-2-one (94\% ee); 6) 9:1 blend of $(R)$ - and $(S)$-3-hydroxyhexan-2-one; 7) 9:1 blend of $(R)$ - and $(S)$-3-hydroxyhexan-2one plus 2,3 hexanedione; and 8) generic blend of all four 2,3hydroxyhexanone stereoisomers. Error bars represent 1 S.E. $(N=$ 15 replicates per mean). Bars marked with asterisks are significantly different from pooled control treatments when tested with preplanned orthogonal contrasts: *, **, and $* * *$ indicate $P<0.05,0.01$, and 0.001 , respectively
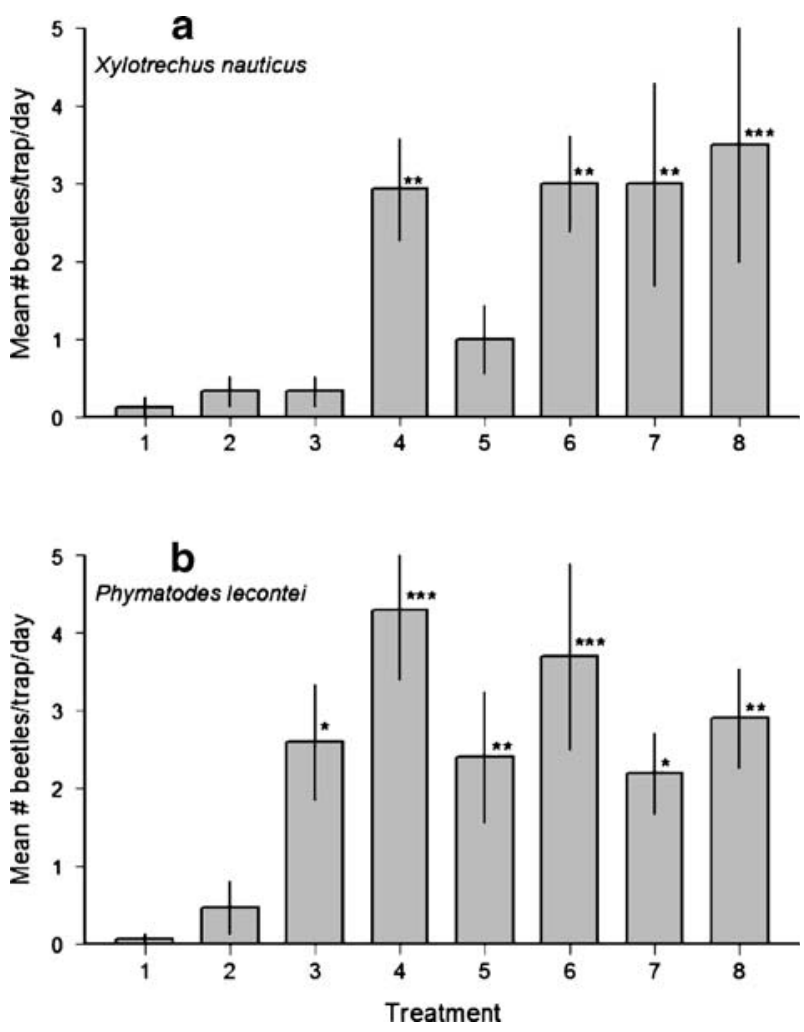
Racemic 2-methylbutan-1-ol was more attractive than controls to both sexes of $P$. lecontei (Fig. 2b), suggesting that it is a male-produced aggregation pheromone component. Furthermore, all of the treatments that contained hydroxyhexanones attracted more $P$. lecontei than controls, including the $(S)$-3-hydroxyhexan-2-one treatment. Treatments that contained the $(R)$-enantiomer were not more attractive than the $(S)$-enantiomer (contrast $P>$ 0.2 ), and the $(R)$-enantiomer was no more attractive than the 9:1 blend of $(R)$ - and $(S)$-3hydroxyhexan-2-one $(P>0.5)$, indicating no inhibition of attraction by the $(S)$-enantiomer. In addition, the $(R)$-enantiomer was no more attractive than the generic blend of hydroxyhexanones $(P>0.1)$, suggesting that the 2-hydroxyhexan-3-one isomers in the generic blend were not inhibitory. Sex ratios of beetles were female biased for the $(S)$ treatment, and male biased in the 9:1 blend treatment (Table 1), but not significantly different from 1:1 for the remaining treatments.

Too few N. m. modestus were captured for rigorous statistical analysis of all the treatment effects. Nevertheless, all 15 beetles were captured in traps baited with the compound that the males produced, $(R)$-3-hydroxyhexan-2-one, alone or in blends (Table 1). The strength of the response to these compounds was revealed when data from the four treatments that contained $(R)$-3-hydroxyhexan-2-one (including 9:1 $(R)$ - and $(S)$-3hydroxyhexan-2-one, with and without 2,3-hexanedione, and the generic hydroxyhexanones) were pooled and contrasted with data from the four treatments that did not contain it (blank and ethanol controls, 2-methylbutan-1-ol and (S)-3-hydroxyhexan-2-one treatments) and tested by chi square analysis $\left(\chi^{2}=15.0 ; P<0.001\right)$.

The small numbers of $P$. decussatus (also captured in the generic screening study; Table 1) and B. gemmulatus that were caught in the targeted bioassays prevented proper assessment of their responses to the test compounds. However, it is noteworthy that adults of these species also were caught in traps baited with $(R)$-3-hydroxyhexan-2-one, as a single component or in blends, with the exception of three $P$. decussatus caught in a trap baited with racemic 2-methylbutan-1-ol (Table 1).

A total of eight adults of the trogositid beetle Temnochila chlorodia were caught in traps baited with ethanol (one beetle), $(R)$-3-hydroxyhexan-2-one (two beetles), (S)-3-hydroxyhexan2-one (one beetle), and generic hydroxyhexanones (four beetles), but numbers were too low to determine whether catch was caused by attraction to the lures or simply because of chance. T. chlorodia is a predator of scolytid beetles and is attracted by their pheromones (Bedard et al. 1980; Seybold et al. 1992; Dahlsten et al. 2004). Consequently, it seems reasonable to suppose that it also might be attracted to volatiles associated with other potential prey.

\section{Location of Pheromone Glands}

The prothoraces of males of all five of the cerambycine species that were captured had pores similar in structure to the pheromone gland pores of cerambycine species previously studied (Fig. 3; Ray et al. 2006). Pores were present on the pleura of all five species, but also on the episterna and sterna of $X$. nauticus, $P$. lecontei, $P$. $d$. decussatus, and $B$. gemmulatus, and the pronota of $B$. gemmulatus and $N$. m. modestus. Females had cuticular depressions that contained a single central seta and no pores (Fig. 3). Pore indentations of male $X$. nauticus and P. lecontei (Fig. 3a,b) were more deeply invaginated than those of the remaining species, and were much broader in $B$. gemmulatus than in species examined previously (Fig. 3e; Ray et al. 2006).

Histological sectioning of prothoraces of adult $X$. nauticus and P. lecontei was problematical because gut and muscle tissue did not fully solidify after infiltration and embedding. As a result, the cuticle separated from underlying tissues during sectioning. Sections of $P$. lecontei 

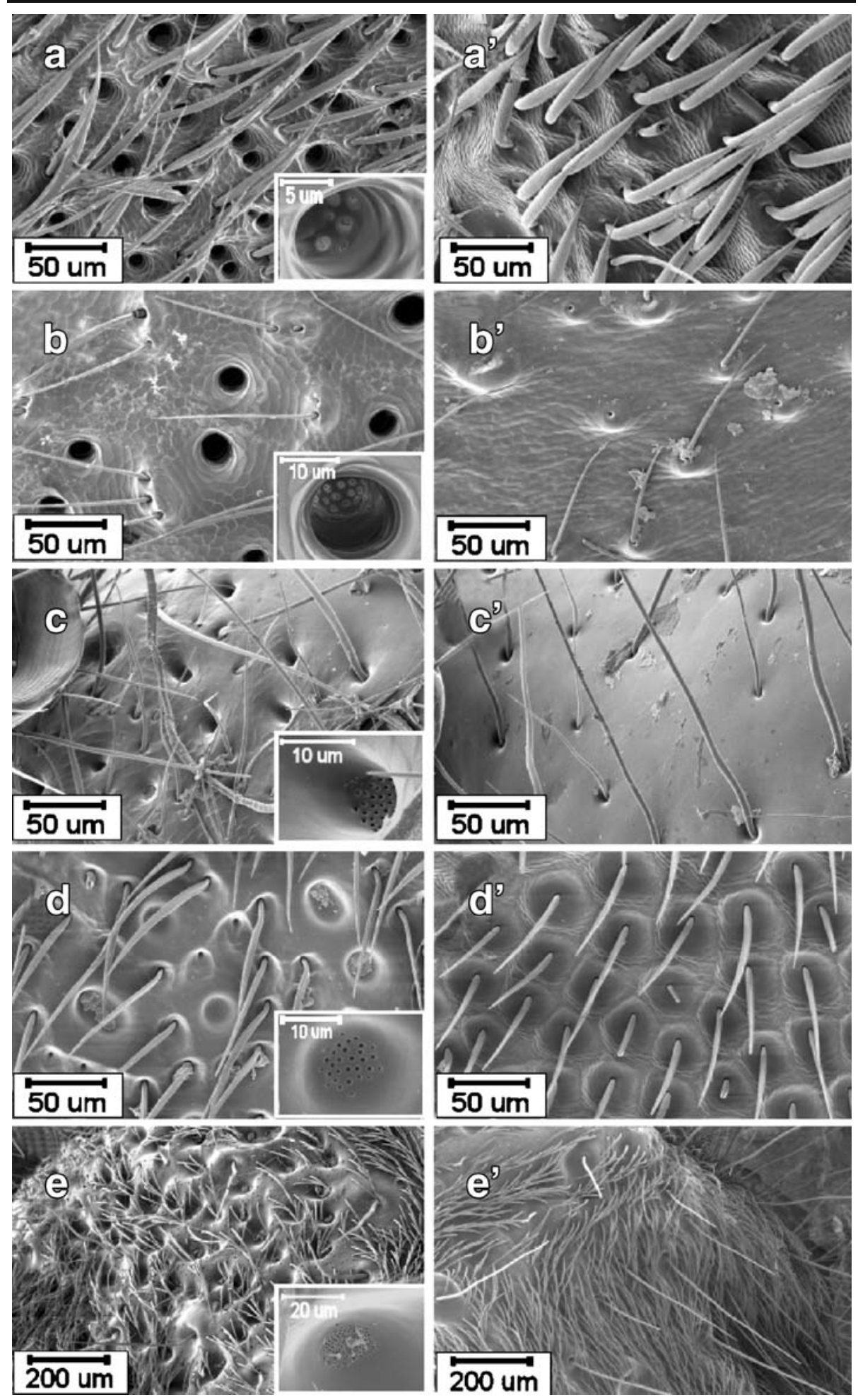
4Fig. 3 Scanning electron micrographs of the pronotum of adult: Xylotrechus nauticus (a), Phymatodes lecontei (b), Phymatodes decussatus decussatus (c), Neoclytus modestus modestus (d), and Brothylus gemmulatus (e). For each species, male prothorax is on the left (inset, close-up of pore indentation) and female prothorax on the right (primed letters)

(not shown) were of such poor quality that no conclusions could be drawn about sexual differences in morphology. However, sections of $X$. nauticus revealed that males had a layer of cells underlying the cuticle, with cells connected to pores lying within depressions in the cuticle (Fig. 4a) that resembled the type III gland cells associated with pheromone glands of Neoclytus a. acuminatus F. and N. mucronatus mucronatus (F.) (Lacey et al. 2007a, b). This cellular layer was absent in prothoracic sections of females (Fig. 4b).

\section{Discussion}

The results of the initial field screening experiments provided support for our hypothesis that the 2,3-hydroxyketone pheromone structural motif is conserved among cerambycine species. Furthermore, this study demonstrated that species could be targeted for detailed pheromone identification by trapping live adults with generic blends of hydroxyhexanones,

Fig. 4 Transverse histological sections through prothoraces of adult Xylotrechus nauticus: (a) male $(\times 400 ; \mathrm{gp}=$ gland pore; $\mathrm{g}=$ gland cells); (b) female $(\times 400)$. Fig. 1
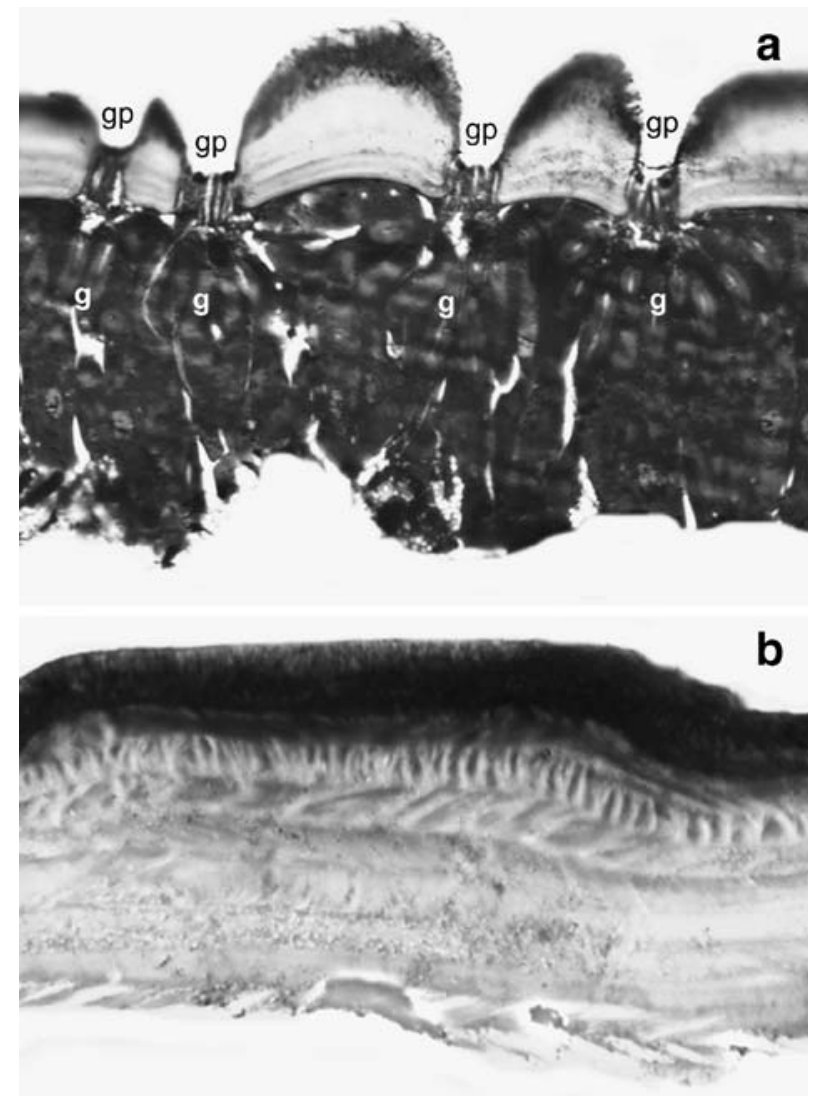
followed by collection and analysis of the volatile compounds released by the live beetles. Targeted trapping with likely pheromone components has an advantage over trapping with less selective baits such as host plant volatiles (e.g., Chénier and Philogène 1989; Sakakibara et al. 1997), because the pheromone components are likely to be much more specific to cerambycid beetles. This was borne out by the fact that our pheromone-baited traps captured only a few specimens of other types of insects, facilitating field processing of samples and collection of live beetles for pheromone identification. The selectivity of the pheromone lures may be useful in situations where pheromone-baited traps are deployed in large numbers and checked by personnel with little entomological training, as might occur during efforts to detect and delineate the range of invasive species.

The three cerambycine species that were attracted in field bioassays represent two tribes of the Cerambycinae: the Clytini ( $X$. nauticus and $N$. m. modestus), and the Callidiini (Phymatodes lecontei; Monné and Hovore 2005). Larvae of all of these species develop in oaks (Linsley 1964), but there is scant information about their biology, life histories, or behavior (Chemsak 1963; Linsley 1964).

The structure of the pheromone components of $X$. nauticus and N. m. modestus, 3hydroxyhexan-2-one, is consistent with the diol/hydroxyketone structural motif of pheromones reported for another four North American cerambycine species (see Lacey et al. 2004, 2007a). In fact, we now know from ongoing work that pheromones of several additional cerambycine species also appear to be comprised of (R)-3-hydroxyhexan-2-one as a single component or in combination with other structurally related compounds (Table 2). Interestingly, subsets of the species listed in Table 2 are sympatric and overlap in flight season, including most of the Californian species (Linsley 1962, 1964) and all of the Illinois species (Yanega 1996; Lacey et al. 2004). This frequent occurrence of ( $R$ )-3-hydroxyhexan-2one among cerambycine species, and the response of five sympatric species to the same compound in the field trials described herein, further attest to its important role in cerambycine mating systems. The similar responses of adult $X$. nauticus to all baits that contained $(R)$-3-hydroxyhexan-2-one, including the 9:1 mixture with the $(S)$ enantiomer and the generic blend of stereo- and regioisomers, suggest that the minor component, $(S)$-3hydroxyhexan-2-one, was not necessary for attraction, and that the 2-hydroxyhexan-3-one regioisomers had no inhibitory effect for this species. In contrast, Lacey et al. (2007a) showed that N. m. mucronatus was more strongly attracted to $(R)-3$-hydroxyhexan-2-one than to racemic 3-hydroxyhexan-2-one, indicating that the presence of the wrong enantiomer was indeed inhibitory for that species. Furthermore, the activity of the natural pheromone of male $N$. a. acuminatus, $(2 S, 3 S)$-hexanediol, was not affected by the presence of the other enantiomer, but one or both of the $\left(2 R^{*}, 3 S^{*}\right)$-diastereomers were inhibitory (Lacey et al. 2004). We conclude from these limited data that certain species within communities of cerambycines may be only weakly attracted or not attracted at all to traps baited with generic lures. Nevertheless, even weak attraction may be sufficient to garner sufficient specimens for pheromone collection and identification. This is particularly true given that individual beetles produce relatively large amounts of pheromone. For example, the eight male $X$. nauticus that produced pheromone in the quantitation study yielded an average of almost $100 \mu \mathrm{g}$ of pheromone per individual per day, with one individual producing $310 \mu \mathrm{g}$ per day. This quantity of pheromone is sufficient for obtaining mass, GC-Fourier transform infrared (FTIR), and even nuclear magnetic resonance (NMR) spectra, as well as for microchemical tests, suggesting that it should be possible to identify even a previously unknown pheromone component from volatiles collected from a single beetle.

It must also be emphasized that it is unlikely that production of pheromone occurs at a constant rate throughout the day and night. Instead, the pheromone is probably produced 
Table 2 Male Cerambycinae that produce $(R)$-3-hydroxyhexan-2-one

\begin{tabular}{|c|c|c|c|c|}
\hline Tribe & Species & $\begin{array}{l}\text { Relative } \\
\text { proportion }^{\mathrm{a}}(\%)\end{array}$ & $\begin{array}{l}\text { Location } \\
\text { of study }\end{array}$ & Reference \\
\hline Anaglyptini & $\begin{array}{l}\text { Anaglyptus } \\
\text { subfasciatus Pic }\end{array}$ & $>80$ & Japan & Leal et al. 1995 \\
\hline Callidiini & $\begin{array}{l}\text { Pyrrhidium } \\
\text { sanguineum }(\mathrm{L} .)\end{array}$ & $>90$ & Europe & Schröder et al. 1994 \\
\hline Callidiini & $\begin{array}{l}\text { Hylotrupes } \\
\text { bajulus (L.) }\end{array}$ & 75 & Europe & Fettköther et al. 1995 \\
\hline Clytini & $\begin{array}{l}\text { Megacyllene robiniae } \\
\text { (Förster) }\end{array}$ & 20 & Illinois, USA & Unpublished data \\
\hline Clytini & $\begin{array}{l}\text { Neoclytus balteatus } \\
\text { LeConte }\end{array}$ & 80 & $\begin{array}{l}\text { California, } \\
\text { USA }\end{array}$ & Unpublished data \\
\hline Clytini & $\begin{array}{l}\text { Neoclytus } m . \\
\text { modestus Fall }\end{array}$ & 100 & $\begin{array}{l}\text { California, } \\
\text { USA }\end{array}$ & Present study \\
\hline Clytini & $\begin{array}{l}\text { Neoclytus mucronatus } \\
\text { mucronatus (F.) }\end{array}$ & 100 & Illinois, USA & Lacey et al. $2007 \mathrm{a}$ \\
\hline Clytini & $\begin{array}{l}\text { Neoclytus mucronatus } \\
\text { vogti Linsley }\end{array}$ & 100 & $\begin{array}{l}\text { Arizona, } \\
\text { USA }\end{array}$ & Unpublished data \\
\hline Clytini & $\begin{array}{l}\text { Sarosesthes } \\
\text { fulminans (F.) }\end{array}$ & $>80$ & Illinois, USA & Unpublished data \\
\hline Clytini & $\begin{array}{l}\text { Xylotrechus arvicola } \\
\text { (Olivier) }\end{array}$ & 100 & Spain & $\begin{array}{l}\text { Núñez and Hall, } \\
\text { unpublished data }\end{array}$ \\
\hline Clytini & $\begin{array}{l}\text { Xylotrechus } \\
\text { colonus (F.) }\end{array}$ & $>40$ & Illinois, USA & Unpublished data \\
\hline Clytini & $\begin{array}{l}\text { Xylotrechus nauticus } \\
\text { (Mannerheim) }\end{array}$ & 100 & $\begin{array}{l}\text { California, } \\
\text { USA }\end{array}$ & Present study \\
\hline Elaphidiini & $\begin{array}{l}\text { Anelaphus pumilus } \\
\text { (Newman) }\end{array}$ & 100 & Illinois, USA & Unpublished data \\
\hline Trachyderini & $\begin{array}{l}\text { Tragidion armatum } \\
\text { brevipenne Linsley }\end{array}$ & 100 & $\begin{array}{l}\text { California, } \\
\text { USA }\end{array}$ & Unpublished data \\
\hline
\end{tabular}

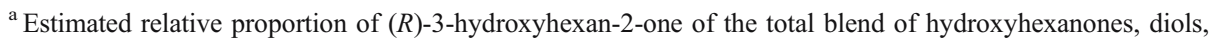
and diones of $\mathrm{C}_{6}$ and $\mathrm{C}_{8}$ chain length.
}

over a few hours or less, during the period of daily reproductive activity typical of each species. For example, in previous studies, male beetles periodically adopted a characteristic posture during which pheromone was produced (Lacey et al. 2004, 2007b), and male $X$. nauticus also adopted this posture at intervals throughout the day. Thus, beetles actually may produce pheromones at rates of $100 \mu \mathrm{g} / \mathrm{hr}$ or more. This may explain the relatively large doses of synthetic pheromone (in this study, $25 \mathrm{mg}$ of active compound per lure, being released at $\sim 0.5$ to $1 \mathrm{mg} / \mathrm{hr}$ ) that appear to be necessary to attract significant numbers of cerambycids (e.g., Lacey et al. 2004, 2007a).

The fact that male $X$. nauticus produce an aggregation pheromone and not a sex pheromone was confirmed during our field bioassays with synthetic pheromone, in which similar numbers of males and females were attracted to baited traps. Before this study, the only cerambycid species known to produce aggregation pheromones were $N$. a. acuminatus and N. m. mucronatus (Lacey et al. 2004, 2007a). The fact that both sexes of their congener, $N$. m. modestus, responded to synthetic pheromone in the present study also suggests an aggregative function. Although we captured only female $B$. gemmulatus, the sample size was too small to draw any firm conclusions about the sexual specificity of its pheromone. 
The attraction of both sexes of P. lecontei to 2-methylbutan-1-ol confirmed that it also serves as a male-produced aggregation pheromone. It is possible that adults may have responded even more strongly had we had the correct, insect-produced $(R)$-2-methylbutan1-ol to test, rather than the racemic blend. This compound had not previously been associated with cerambycids, although it has been reported as a defensive compound for other types of beetles (Dettner and Reissenweber 1991). It also has been reported as a plantproduced attractant or kairomone for nitidulid beetles (Lin and Phelan 1991) and palm weevils (Rochat et al. 2000). Males of the cerambycid Hylotrupes bajulus produce the related 1-butanol (Fettköther et al. 1995), which was reported to enhance attraction of adult beetles to $(R)$-3-hydroxyhexan-2-one (Reddy et al. 2005).

The absence of $(R)$ or $(S)$-3-hydroxyhexan-2-one in extracts of headspace volatiles collected from male $P$. leconte $i$ was surprising, given the strong response of both sexes to these compounds or their blend in the field (Table 1). It is possible that male P. lecontei do indeed produce 3-hydroxyhexan-2-one, but not under the unnatural conditions of headspace collection in the laboratory. However, this seems unlikely, given that the male-specific compound (R)-2-methylbutan-1-ol was present in large amounts in those extracts. Alternatively, adult $P$. lecontei may not produce hydroxyhexanones themselves, but rather may have evolved an ability to detect these compounds for exploitation of the communication channel of other cerambycine species as a method of locating larval hosts. Phymatodes lecontei was not only sympatric with $X$. nauticus, but both species had the same pattern of circadian activity. Phymatodes lecontei undoubtedly shares hosts with $X$. nauticus, but nothing is known of the ecological interactions between these species.

The presence of pheromone gland pores on the prothoraces of male $X$. nauticus, $P$. lecontei, and N. m. modestus was consistent with the responses of these species to synthetic pheromone. Males of the remaining two species, P. decussatus and B. gemmulatus, also had gland pores that were missing in females. The structures of pore indentations in $X$. nauticus and P. lecontei were similar to the deeply invaginated indentations of Xylotrechus quadripes Chevrolat, and also those of the cerambycine Achryson surinamum (L.) (Ray et al. 2006). The shallower pore indentations and the distribution of pores in $N$. m. modestus, $P . d$. decussatus, and B. gemmulatus were similar to those of the congeners $N$. a. acuminatus and N. m. mucronatus, as well as other cerambycine species (Lacey et al. 2007b; Ray et al. 2006). The layer of glandular cells associated with prothoracic pores of male $X$. nauticus provided further evidence that these pores are the site of pheromone release.

Our capture of multiple cerambycine species at a single location over a short period of time demonstrates the potential for using generic blends of likely pheromone components in the development of tools for monitoring and control of the many cerambycine species that are pests (e.g., Solomon 1995). These generic blends can be synthesized much more quickly and cheaply than the individual regioisomers or stereoisomers, providing economical lures for screening or survey trials. This study also validates the concept of using generic blends of candidate pheromones as a lead-in method for initiating the identification of pheromone components for cerambycid beetles. Furthermore, the strong attraction of several of the study species to generic hydroxyhexanones (19 beetles of one species were caught in a single trap in 1 day) demonstrates the potential for using pheromone-baited traps as a sensitive method for detecting and monitoring specific cerambycid species.

Overall, the results reported here and analogous results from previous studies of cerambycid semiochemistry suggest numerous unanswered questions relating to the production and use of pheromones within this family. For example, given that three species were attracted simultaneously at our study site with the single pheromone component $(R)-3$ - 
hydroxyhexan-2-one, what mechanisms might limit cross attraction between species? Despite the fact that we found several minor components in extracts (e.g., $(S)$-3hydroxyhexan-2-one and 2,3-hexanedione in $X$. nauticus), there was no evidence that a particular species produced one or more compounds that inhibited cross-attraction of sympatric species, as frequently occurs with minor components of the pheromone blends of other insects (e.g., scarab beetles, Leal 1999; moths, Cardé and Haynes 2004). We also found no evidence that attraction to the main component, $(R)$-3-hydroxyhexan-2-one, was increased by addition of the possible minor components $(S)$-3-hydroxyhexan-2-one and 2,3hexanedione, that might provide a unique pheromone channel for a particular species. Furthermore, some of our study species have similar diurnal patterns of reproductive activity and exploit similar hosts, and so it seems unlikely that they are partitioning their reproductive activities in time or space.

We also do not know why male cerambycid beetles produce quantities of attractant pheromones that are several orders of magnitude larger than the amounts typically produced by other insects of similar size. For example, males of the stink bug Acrosternum hilare (Say) produce $<1 \mu \mathrm{g}$ of pheromone per hour (McBrien et al. 2001), and the pheromone emission rates of female lepidopterans are typically much less than $1 \mu \mathrm{g} / \mathrm{hr}$ (e.g., Heliothis virescens [F.]; Pope et al. 1982). However, pheromone production is substantial in males of arctiid moths such as Utetheisa ornatrix (L.), females of which assess the fitness of males by their ability to produce pheromone (Eisner and Meinwald 2003). A similar situation may occur with the cerambycid species described here, with females assessing the fitness of males by their production of pheromone.

It is also unclear why the pheromones attracted both sexes of most of our study species. Typically, insects are thought to produce aggregation pheromones when there is a benefit that will accrue to all signaling and responding individuals, such as the assembly of a critical mass of bark beetles to overwhelm defenses of host trees (Schlyter and Birgersson 1999), or the aggregation of chemically defended aposematic individuals (e.g., Al Abassi et al. 1998). However, in the case of the cerambycid species in this study, there is no obvious benefit to aggregation with regard to attack of hosts because the beetles use dying or dead hosts (Linsley 1962, 1964). Furthermore, X. nauticus and $P$. lecontei apparently are not aposematic (Linsley 1962, 1964) and have no obvious chemical defenses, so it seems unlikely that they would aggregate for mutual defense. However, production of large quantities of pheromone is costly, and aggregation may be of selective advantage if "satellite males" assembling in the vicinity of conspecific males can intercept responding females (see Moore et al. 1995).

As this research continues, we hope to answer some of these questions and expand our understanding of the role of semiochemicals as mediators of reproductive behaviors within this diverse insect family. In particular, a more detailed understanding of taxonomic patterns of pheromone chemistry and pheromone use would be tremendously valuable for facilitating the identification of pheromones of invasive cerambycine species as they inevitably arrive in North America (see Haack 2006) or other areas of the world. This information in turn would provide the means for developing methods for detecting, controlling, and even potentially eradicating invasive species.

Acknowledgments We thank Frank Hovore (deceased), Douglas Yanega, and Ian Swift for assistance with identification of beetle species, Scott Robinson for help with SEM and histological sectioning work, Adam Martinsek for assistance with the statistical analysis, James Nardi for access to microscopy equipment, and Mariana Krugner and Ian Wright for technical assistance. We thank Carole Bell and Santa Rosa Plateau Reserve, Riverside Co., California, for access to field sites. The SEM and histology research was made 
possible through collaboration with Bugscope, The Imaging Technology Group, Beckman Institute for Advanced Science and Technology, University of Illinois at Urbana-Champaign (http://bugscope.beckman. uiuc.edu/). This project was supported by funds from the Exotic/Invasive Pests and Diseases Research Program, University of California, under USDA-CSREES Grant No. 2004-34439-14691, the Alphawood Foundation of Chicago, and Hatch Project \#CA-R*ENT-5181H to JGM.

\section{References}

Al Abassi, S., Birkett, M. A., Pettersson, J., Pickett, J. A., and Woodcock, C. M. 1998. Ladybird beetle odour identified and found to be responsible for attraction between adults. Cell. Mol. Life Sci. 54:876-879.

Bedard, W. D., Wood, D. L., Tilden, P. E., Lindahl, K. Q., Jr., Silverstein, R. M., and Rodin, J. O. 1980. Field responses of the western pine beetle and one of its predators to host- and beetle-produced compounds. J. Chem. Ecol. 6:625-641.

CARDÉ, R. and HAYNES, K. F. 2004. Structure of the pheromone communication channel in moths, pp. 283332, in R. T. Cardé and J. G. Millar (eds.). Advances in Insect Chemical Ecology. Cambridge University Press, Cambridge, United Kingdom.

CHEMSAK, J. 1963. Observations on the adult behavior of Xylotrechus nauticus. Pan-Pac. Entomol. 39:213-214.

ChÉnier, J. V. R. and Philogène, B. J. R. 1989. Field responses of certain forest Coleoptera to conifer monoterpenes and ethanol. J. Chem. Ecol. 15:1729-1745.

Dahlsten, D. L., SiX, D. L., Rowney, D. L., Lawson, A. B., Erbilgin, N., and Raffa, K. F. 2004. Attraction of Ips pini (Coleoptera: Scolytinae) and its predators to natural attractants and synthetic semiochemicals in Northern California: Implications for population monitoring. Environ. Entomol. 33:1554-1561.

Dettner, K. and Reissenweber, F. 1991. The defensive secretion of Omaliinae and Proteininae (Coleoptera: Staphylinidae): its chemistry, biological and taxonomic significance. Biochem. Syst. Ecol. 19:291-303.

EISNER, T. and MEINWALD, J. 2003. Alkaloid-derived pheromones and sexual selection in Lepidoptera, pp. 341-368, in G. J. Blomquist and R. G. Vogt (eds.). Insect Pheromone Biochemistry and Molecular Biology. Elsevier Academic Press, Amsterdam.

Fettköther, R., Dettner, K., Schröder, F., Meyer, H., Francke, W., and Noldt, U. 1995. The male pheromone of the old house borer Hylotrupes bajulus (L.) (Coleoptera: Cerambycidae): identification and female response. Experientia 51:270-277.

HAACK, R. A. 2006. Exotic bark- and wood-boring Coleoptera in the United States: recent establishments and interceptions. Can. J. For. Res. 36:269-288.

Lacey, E. S., Ginzel, M. D., Millar, J. G., and HanKs, L. M. 2004. Male-produced aggregation pheromone of the cerambycid beetle Neoclytus acuminatus acuminatus. J. Chem. Ecol. 30:1493-1507.

Lacey, E. S., Moreira, J. A., Millar, J. G., Ray, A. M., and HanKs, L. M. 2007a. Male-produced aggregation pheromone of the longhorned beetle Neoclytus mucronatus mucronatus. Entomol. Exp. Appl. 122:171-179.

LACEY, E. S., RAY, A. M., and HANKS, L. M. 2007b. Calling behavior of the cerambycid beetle Neoclytus acuminatus acuminatus. J. Insect Behav. 20:117-128.

LEAL, W. S. 1999. Scarab beetles, pp. 51-68, in J. Hardie and A. K. Minks (eds.). Pheromones of Nonlepidopteran Insects Associated with Agricultural Plants. CABI Publishing, Wallingford, UK.

Leal, W. S., Shi, X., Nakamuta, K., Ono, M., and Meinwald, J. 1995. Structure, stereochemistry, and thermal isomerization of the male sex pheromone of the longhorn beetle Anaglyptus subfasciatus. Proc. Natl. Acad. Sci. U. S. A. 92:1038-1042.

LIN, H. and PhELAN, P. L. 1991. Identification of food volatiles attractive to Glischrochilus quadrisignatus and Glischrochilus fasciatus (Coleoptera: Nitidulidae). J. Chem. Ecol. 17:2469-2480.

Linsley, E. G. 1962. The Cerambycidae of North America, Part III: Taxonomy and classification of the subfamily Cerambycinae, Tribes Opsimini through Megaderini. Univ. Calif. Publ. Entomol. 21:1-163.

LinSLEY, E. G. 1964. The Cerambycidae of North America, Part V: Taxonomy and classification of the subfamily Cerambycinae, Tribes Callichromini through Ancylocerini. Univ. Calif. Publ. Entomol. 22:1-197.

Mcbrien, H. L., Millar, J. G., Gottlieb, L., Chen, X., and Rice, R. E. 2001. Male-produced sex attractant pheromone of the green stink bug, Acrosternum hilare. J. Chem. Ecol. 27:1821-1839.

Monné, M. A. and Hovore, F. T. 2005. Checklist of the Cerambycidae (Coleoptera) of the Western Hemisphere. BioQuip Publications, Rancho Dominguez, CA. 
Moore, A. J., Reagan, M. L., and Haynes, K. F. 1995. Conditional signaling strategies-effects on ontogeny, social experience and social status on the pheromonal signal of male cockroaches. Anim. Behav. 50:191-202.

Polysciences. 2003. Poly/Bed ${ }^{\circledR} 812$ Embedding Media/ DMP-30 Kit and Poly/Bed ${ }^{\circledR} 812$ Embedding Media. Technical Data Sheet \#233. Polysciences, Inc. Warrington, PA.

Pope, M. M., GASTON, L. K., and BAKER, T. C. 1982. Composition, quantification, and periodicity of sex pheromone gland volatiles from individual Heliothis virescens females. J. Chem. Ecol. 8:1043-1055.

Ray, A. M., LACEY, E. S., and HANKS, L. M. 2006. Predicted taxonomic patterns in pheromone production by longhorned beetles. Naturwissenschaften 93:543-550.

RedDY, G. V. P., FeTtKöther, R., NOLDT, U., and DETNER, K. 2005. Capture of females Hylotrupes bajulus as influenced by trap type and pheromone blend. J. Chem. Ecol. 31:2169-2177.

Rochat, D., Meillour, P. N., Esteban-Duran, J. R., Malosse, C., Perthuis, B., Morin, J. P., and DÉSCOINS, C. 2000. Identification of pheromone synergists in American palm weevil, Rhynchophorus palmarum, and attraction of related Dynamis borassi. J. Chem. Ecol. 26:155-187.

SAKAKIBARA, Y., YAMANE, A., IWATA, R., and YAMADA, F. 1997. Evaluation of beetle capture in traps as compared with manual capture on flowers in a long-term investigation in a beech forest. J. For. Res. 2:233-236.

SAS Institute. 2001. SAS/STAT User's Guide for Personal Computers, Release 8.01. SAS Institute, Cary, NC.

SChlyter, F. and Birgersson, G. A. 1999. Forest beetles, pp. 113-148, in J. Hardie and A. K. Minks (eds.). Pheromones of Non-Lepidopteran Insects Associated with Agricultural Plants. CABI Publishing, Wallingford, UK.

Schröder, F., Fettköther, R., Noldt, U., DetTner, K., KÖNIG, W. A., and Franke, W. 1994. Synthesis of (3R)-3-hydroxy-2-hexanone, $(2 R, 3 R)$-2,3-hexanediol and $(2 S, 3 R)$-2,3-hexanediol, the male sex pheromone of Hylotrupes bajulus and Pyrrhidium sanguineum (Cerambycidae). Liebigs Ann. Chem. 1994:1211-1218.

Seybold, S. J., Teale, S. A., Wood, D. L., Zhang, A., Webster, F. X., Lindahl, K. Q., Jr., and Kubo, I. 1992. The role of lanierone in the chemical ecology of Ips pini (Coleoptera: Scolytidae) in California. $J$. Chem. Ecol. 18:2305-2329.

SOKAL, R. R. and RoHLF, F. J. 1995. Biometry, 3rd ed. W. H. Freeman, New York, NY.

Solomon, J. D. 1995. Guide to Insect Borers in North American Broadleaf Trees and Shrubs. USDA For. Serv. Agr. Handbook 706.

Sweeney, J., Gutowski, J. M., Price, J., and De Groot, P. 2006. Effect of semiochemical release, killing agent, and trap design on detection of Tetropium fuscum (F.) and other longhorn beetles (Coleoptera: Cerambycidae). Environ. Entomol. 35:645-654.

YANEGA, D. 1996. Field Guide to Northeastern Longhorned Beetles (Coleoptera: Cerambycidae). Manual 6, Illinois Natural History Survey, Urbana, IL. 